\title{
WORK ORGANIZATION AND TRAINING IN AMERICAN ENTERPRISES
}

\section{Paul Osterman}

Interest in new forms of work organization has exploded in America. Behind this emphasis is the view that gains in productivity depend upon adoption of new modes of work organization, models which entail innovations such as broad job definitions, use of teams, employee problem-solving groups, and quality circles. Indeed, the U.S. Department of Labor has established an "Office of the American Workplace" aimed at encouraging the spread of these innovations.

Despite the growing policy commitment to these new forms of work organization several basic questions remain unanswered. We do not know how many firms are engaged in reorganizing work nor can we explain which firms undertake these efforts and which do not. With respect to the first question one widely cited national estimate comes from the Commission on the Skills of the American Workforce, which claimed that five percent of employers are so-called High Performance Work Organizations (1990). However, the Commission has never described clearly the source of this estimate.

With regard to the second question, systematic study of the determinants of adoption, the literature is extremely sparse. There is little or no systematic research that takes work organization as the dependent variable and tests hypotheses found in the literature. Adequate data have not hithertofore been available to take the discussion very much beyond anecdotal evidence.

The substantial interest in diffusing these new forms of work organization has raised the ancillary question of whether firms and schools are providing enough training to enable effective use of these systems. After a long social science debate concerning the trajectory of skill, the presumed tendency is now in the direction of upskilling and the question is under what circumstances it is occurring and whether the pace is fast enough. This perspective is given additional weight by data which seem to show a substantial twist in the wage structure in the direction of increased demand for skill (Levy and Murnane 1993; Katz and Murphy 1992).

The research on the determinants of training across organizations is also less than satisfactory. There are several representative national surveys of individuals (such as a supplement to the Current Population Survey and the National Longitudinal Survey of Youth) as well as some surveys of firms. Examples of firm surveys include those conducted by the American Society of Training and Development (Carnevale 
1990), The Conference Board (Lusterman 1985), and Training Magazine. However, the technical quality of the employer surveys is somewhat mixed. ${ }^{1}$

These surveys tend to show that the aggregate volume of training expenditure is quite high and that the distribution of training is very much biased toward managers and white-collar workers and away from blue-collar employees. (Lynch 1990; Osterman and Kochan 1993; Brown 1990). However, these studies typically contain little contextual information on firms and so we cannot understand which kinds of employers do what.

The emphasis on work organization and productivity has also added a slightly different twist to the skills debate. The older discussion of the skill trajectory of new technology often carried with it the implicit assumption that once the technology was in place how it was used was foreordained. This "technological determinism" view left little space for choice. The more recent discussion, with its emphasis on international comparisons, shows quite clearly that the same technology can be deployed in different ways and with different impacts upon skill. This is the central lesson of the international automobile industry research (MacDuffie 1991; Womack et al. 1990; Brown et al. 1991; Adler 1993). This finding in turn transforms the older question- "what is the impact of technology upon skill" into the issue now more commonly debated in policy circles-"how much training is there and why do some employers train more than others?" In other words, skill has come to be seen as the outcome variable which in turn is determined by choices which vary across employers.

This chapter takes up three questions, which emerge from the foregoing discussion:

- What is the distribution of work organization practices across American firms?

- What determines of which employers adopt the bundle of practices which are currently termed "high performance" practices?

- How can the training practices of establishments be related to the nature of their work organization and other aspects of establishment structure? This includes, but is not limited to, the more narrow but important question of whether it is true that establishments which adopt elements of High Performance Work Organizations (HPWO) tend to provide more training for their employees than do other enterprises.

The chapter employs a new, nationally representative, survey of establishmentsdescribed in the next section - to answer these questions. Following the description of the survey, the chapter analyzes the incidence of shifts in work organization and estimates several models explaining variation across establishments in the use of these new work systems. The chapter then turns to training and seeks both to explain variation in training effort across establishments and to understand whether shifts in work organization are associated with heightened training. The chapter concludes with a brief discussion of the relevance of these findings to Germany. As noted earlier, the chapter draws substantially from two previous articles (Osterman 1994 and Osterman, forthcoming). 


\section{THE SURVEY}

The survey upon which this chapter is based was conducted in the summer and fall of 1992 and contains 875 observations on American establishments. ${ }^{2}$ An establishment is defined as a business address and is distinct from a company. For example, each assembly plant of General Motors is an establishment, as is the corner gas station. Establishment-based sampling is more likely to produce accurate data on work practices than questions addressed to officials in corporate headquarters. The sampling universe was the Dun and Bradstreet establishment file which purports to be a list of all establishments in the nation. ${ }^{3}$ Considerable effort was devoted to the selection of the most knowledgeable respondent within the establishment and this person was often not on the human resource staff. ${ }^{4}$

The sampling was limited to establishments with fifty or more employees in nonagricultural industries. ${ }^{5}$ Nonprofit organizations were also eliminated. The sampling was size stratified in order to create adequate samples within size categories and appropriate weights are used to create a representative sample of establishments. The response rate was 65.5 percent. $^{6}$

A final point regarding the survey procedure concerns the unit of analysis within the establishment. Many variables were collected for the entire establishment. However, detailed information on work organization was obtained only for CORE employees. This is because no single answer regarding, say, job training is likely to be applicable to all occupational groups within an establishment. It was not practical to collect ILM data on all job families and so the notion of a CORE job was developed. The CORE job was defined as:

The largest group of non-supervisory, non-managerial workers at this location who are directly involved in making the product or in providing the service at your location. We want you to think of the various groups directly involved in making the product or providing the service and then focus on the largest group. For example, these might be assembly-line workers at a factory or computer programs in a software company, or sales or service representatives in an insurance company.

The distribution of CORE jobs was: 14.3 percent professional/managerial; 19.0 percent sales; 6.0 percent clerical; 18.3 percent service; and 42.3 percent blue-collar.

\section{FLEXIBLE WORK ORGANIZATION}

In order to describe and analyze the distribution of more flexible work systems we must define and operationalize the idea. The problem is that there is no single accepted definition. While it seems fair to say that the many scholars who have written on the topic have the same broad set of practices in mind each author places somewhat different emphasis.

The survey asked about a series of practices (all with respect to the CORE job family) and I will focus on the four most often seen as most central to transformed 
organizations: self-directed work teams, job rotation, use of employee problemsolving groups (or quality circles), and use of Total Quality Management (later in the chapter I will also examine Statistical Process Control but for the present purposes this is too specialized to manufacturing). For each the respondent was asked whether or not the practice was employed in the establishment and if so what percentage of CORE employees were involved. The precise definitions given for each practice are shown in Appendix A. ${ }^{7}$

The first tabular results showed the distribution of each practice for two levels of penetration: whether the practice is used at all and whether at least 50 percent of CORE employees are involved (see Tables 2.1 (a) and 2.1 (b) in Appendix B).

It is clear that if we simply ask whether or not a given practice is used among any fraction of CORE employees then we would conclude that the elements of flexible work are quite widespread. For example, over half of the establishments use teams and 33.5 percent of the establishments employ TQM.

The story becomes different, however, when we examine penetration. Looking at the intermediate category of 50 percent or more employees involved, the rates fall sharply. Each practice falls by roughly 15 percentage points. ${ }^{8}$ Even so, the distribution of self-directed work teams is surprisingly widespread. There is clearly some discontinuity between the extent of usage of this practice and the others.

The manufacturing/blue-collar patterns are similar in that there is a substantial diffusion of the practices at any usage level and there is a drop-off when one sets a 50 percent threshold for participation. Self-directed teams appear less widespread in manufacturing than elsewhere in the economy ${ }^{9}$ but the other practices are more common.

These data lead to the natural question of whether the practices form groups from which emerge identifiable patterns which might be thought of as the new systems discussed in the literature. A second table (Table 2.2) revealed how the practices cluster together when a 50 percent penetration threshold is set (no conclusions are changed when other thresholds are imposed). It appears that there is no single major dominant cluster of practices. There is some representation for each of the possible combinations and in most of the cases the distribution of clusters seems rather even.

A final question, which is virtually imposed by the popular discussion, is whether it is possible to provide a summary figure regarding the use of High Performance Work Organizations. The numerous definitions in the scholarly literature might lead one to suspect that this is a difficult question to answer and nothing in these data suggests otherwise. As already noted, there is no dominant pattern.

Pushed to arrive at a definition, it might be reasonable to characterize an organization as "transformed" if there are at least two practices in place with 50 percent or more of CORE employees involved in each. By this definition 36.6 percent of the entire sample, 43.0 percent of nonmanufacturing, and 35.9 percent of manufacturing establishments are of the new breed. ${ }^{10}$ These estimates are considerably higher than those commonly cited and although the definition is admittedly arbitrary it is likely that the truth is much closer to these figures than to those found in popular accounts. 


\section{Explaining the Distribution of Work Practices}

The next step is to try and understand why some establishments have adopted these various work practices while others have not.

The independent variables are intended to test many of the explanations which have appeared in the literature concerning variation in the adoption of flexible work practices across establishments. These explanations can be clustered in several categories:

\section{Markets and Strategy}

One would expect that the nature of an establishment's competitors and of its market would influence the choice of work systems. However, the relationships are not necessarily simple and straightforward. Consider first competitive pressure. Normally, one might expect that an establishment selling in a market with many competitors will be under pressure to adopt the most productive possible work system and this may indeed lead to elements of flexible work organization. Offsetting this, however, is the consideration that new work systems represent considerable investment and firms which face very competitive market situations may be operating on too tight a margin to undertake these long-run investments. The variable measuring the competitiveness of product markets is called COMPETIV (for definitions see Table 2.3). ${ }^{11}$

In addition to the degree of competition in the market it is also important to consider the identity of the competitors. Much of the pressure to adopt new production systems has come from the example of foreign competitors and this would seem to be strongest for enterprises which compete in international markets. In addition to this market argument it seems reasonable to expect that establishments which operate in international markets are more likely to be exposed to new ideas and practices. ${ }^{12}$ The variable INTERNAT is a dummy variable which takes on the value of " 1 " if the establishment sells in international markets.

A second aspect of an establishment's market concerns its competitive strategy. Much of the current discussion posits that employers face two broad competitive choices, one which implies competing on cost and the other in which the establishment competes on the basis of quality, variety, and service (Piore and Sabel 1984; Cuomo Commission 1988; Kochan and Osterman 1991). In popular discussion the former is referred to as the "low road" and the latter as the "high road," on the assumption that the latter carries with it the implication of more generous employment conditions (wages, etc.) and new work systems.

The survey contained a set of questions intended to distinguish among these strategies. I assigned 100 points to the goal of competing on cost and then asked the respondents to indicate how many points three other competitive strategies-quality, variety, and service-would receive for their establishment in comparison. For example, if competing on quality was twice as important to the establishment as competing on cost it would be assigned 200 points. I employ the 
first principle component of the three variables and this component is termed STRATEGY. Larger values of this variable imply greater use of the "high road" strategy. ${ }^{13}$

\section{Technology}

An important aspect of technology is its complexity. It is reasonable to expect that the gains from the introduction of flexible work systems, and hence the likelihood of observing them, are greater under more rather than less complex technologies. This is measured by the variable SKLEV which takes on the value of "1" if the production process requires high levels of skill and " 0 " otherwise. ${ }^{14}$

\section{Values}

It is well known from anecdotal evidence that firms which appear to observers to be similar with respect to markets, technology, and other structural characteristics nonetheless differ considerably in the human resource practices. ${ }^{15}$ One possibility is that the values of the firm - for example the extent to which the enterprise is seen as a community or a "family" - might be important. This consideration is given weight by the observation that Japanese employers have more of a community or stakeholder view of their enterprise than do Americans and that this helps explain various work practices (Dore 1973; Lincoln and Kalleberg 1990). Kochan et al. (1984) cite management values as an important determinant of HR practices.

About 50 percent of the survey instrument contained a long series of questions about benefits, particularly work-family benefits, and about enterprise values regarding these benefits. This portion of the questionnaire was administered prior to the work organization questions which are the subject of this chapter and hence the respondents' reply on values was unrelated to any suggestion which might have been implanted by the work organization section. In the context of asking about benefits the respondent was asked "In general, what is your establishment's philosophy about how appropriate it is to help increase the well being of employees with respect to their personal or family situations?" Establishments that responded (on a five-point scale) that it was "very" or "extremely" appropriate are assigned "1" on a dummy variable (called VALUE). ${ }^{16}$

\section{Firm Environment}

An increasingly common argument is that some companies fail to transform their work organization because such transformations are long-term investments with considerable upfront costs and uncertainty. Many firms, so it is alleged, face pressures from investors to emphasize short-term profits at the expense of such longterm investments (Porter 1992; Jacobs 1991). The variable HORIZON measures the extent to which the establishment feels such pressure. ${ }^{17}$ 
There are several other environmental features which may influence adoption of new work systems. Establishments which are part of larger organizations (e.g. a branch plant) may receive greater resources, information, and technical assistance in adopting flexible work organization. In addition, they may be more likely to adopt flexible work systems due to isomorphic processes of coercion and mimicry (DiMaggio and Powell 1983; Pfeffer and Cohen 1984; Baron, et al. 1988). A dummy variable LARGER takes on the value of " 1 " if the establishment is part of larger organization.

Size is likely to be related to adoption but the direction is ambiguous. On the one hand, smaller establishments have fewer resources to devote to human resource innovations. This expectation is born out by the literature on training which demonstrates clearly that smaller firms train less than do large ones (Brown 1990). On the other hand, the literature on corporate reorganization and decentralization (as well as the policy discussion of networks) carries with it the implication that smaller establishments, which are not weighed down by the heavy hand of corporate bureaucracy, are more agile and likely to adopt new production techniques. In order to test for possible non-linear effects of size I use a step function, i.e. a series of size dummy variables. The omitted category is 100-499 employees.

The organizational sociology literature suggests that the AGE of an establishment should inversely influence its rate of adoption of innovations because organizational forms tend to be "frozen" at birth (Stinchcomb 1965). Finally, whether or not a union is present seems important although the expected direction of the effect is not clear. There is considerable anecdotal evidence of instances in which unions have opposed the kinds of work rule changes which are implied by transformed systems but there are also instances in which unions have been cooperative and helpful in the process (Katz 1985; Cappelli and Sherer 1989). The net effect is an empirical question. The variable UNION measures whether employees at the establishment are covered by a union.

The models also include dummy variables for the CORE occupations and for industry. ${ }^{18}$

\section{Estimation}

An important difficulty is that there is no single obvious way to estimate a model explaining adoption of flexible work practices. I will take three approaches to an overall characterization of the establishment. First, I will estimate a logit model in which the dependent variable takes on the value of " 1 " if an establishment engages in at least one of the practices at the 50 percent level of penetration and " 0 " otherwise. The advantage is that this is straightforward and readily interpretable. The problem is that it is a bit arbitrary in that an establishment with 49 percent penetration is classified as " 0. " A second approach is to use principal components analysis to create a new variable which is constructed from the percentage of penetration of each of the four practices. I therefore create an index that is the first 
principal component of the four penetration variables and this is treated as a dependent variable. ${ }^{12}$ The third approach is to estimate an ordered probit model in which the dependent variable ranges from zero to four, with each point on the scale representing an additional work practice at the 50 percent penetration level.

Taken together these three dependent variables seem to represent the range of ways one might think about an overall characterization of an establishment. One model (the logit) asks whether any practice is used at all at the 50 percent level, another (the ordered probit) asks how many practices are used at the 50 percent level, and the third (the principal components) treats penetration as a continuous variable and creates an index of the four practices. The advantage of these different models is that we can see which findings are robust across specifications. ${ }^{20}$

Results of the estimations are presented in Table 2.4. The first column contains coefficients for logit model concerning whether the establishment engages in any practices at the 50 percent level of penetration, the second column contains the principle component model and the third column is the ordered probit. The logit coefficients have been transformed so that they have a direct interpretation. ${ }^{21}$

Several conclusions come through quite strongly. Most impressive is the importance of managerial values. In all equations the coefficient on VALUE is positive and significant. This is especially striking given that the question was asked in the context of atritudes toward employees' social and economic welfare and not in regard to specific issues of work organization. Evidently, independent of any productivity gains to be had from flexible work organization, establishments which believe that they have responsibility for employee welfare are more likely to adopt innovative work practices.

It is also striking that enterprises that sell in international markets are more likely to adopt work reform. This result holds independently of the overall level of competition in the market. One possible interpretation of this pattern is that establishments that are exposed to international markets learn more quickly than do others about alternative work practices. ${ }^{22}$

The third variable that produces consistently strong results is skill level. As the skill levels required by an enterprise's technology increase so does the use of the various work organization innovations.

These models also support the view that establishments which follow the "high road" are more likely to adopt flexible work practices. In addition, being part of a larger enterprise, i.e. being a branch plant or office, also increases the likelihood of adoption of elements of flexible work organization. Finally, smaller enterprises, the lowest category and the omitted 100-499 category, seem more likely to use innovative work practices.

In none of the equations is there evidence in support of the time horizons argument, nor do the age or union status of an establishment appear to be very important. $^{23}$ 


\section{PAUL OSTERMAN}

\section{TRAINING}

We now turn to a more careful examination of the determinants of training and how training effort is related to shifts in work organization.

It is quite difficult to devise questions which accurately capture the training effort of firms. Firms do not keep good or standardized data on their training expenditures. When asked to estimate the amount spent on training some firms will estimate their actual program costs while others will compute program costs plus the costs of the employee's time spent in the program while still others will impute an overhead rate to cover fixed costs (facilities, training staff, etc.).

To complicate the measurement problem further, a great deal of employee development or "training" occurs informally on their job. Supervisors, coworkers, mentors, etc. all are important "trainers" for employees as they improve their proficiency.

To obtain estimates of training effort which were consistent across establishments the survey asked about a relatively narrow, but still important, form of training: the fraction of the CORE employees who attended formal off-the-job training (which could occur in vestibules, rooms at the work site, or in educational institutions). In addition, we asked about the number of days per year spent in such training.

Table 2.5 confirms that two broadly held views are supported in these data. Blue-collar employees receive less training (in the sense that a smaller percent receive it) than do white-collar workers. In addition, for blue-collar workers training increases with establishment size. The latter finding, however, is not true for white-collar/professional employees, for whom the relationship between establishment size and training is the inverse of what we would expect. For those employees who do receive formal off-the-job training the training time spent does not seem to vary a great deal by occupation or establishment size.

\section{Explaining the Variation in Firm Training Practices}

Why do some firms provide more training than do others? In this section I will test a number of explanations commonly found in the literature. The dependent variable in the models that follow is the percent of the CORE employees who receive formal off-the-job training.

Work Organization The key issue in the current debate, as I have already noted, is whether newer "transformed" forms of work organization require more skills and training. I will enter these variables in three ways into models explaining training effort. Initially I will simply use an index which is the number of practices which are in place at the fifty percent or more level of involvement by CORE employees. This index can range from zero to five. ${ }^{24}$ In subsequent models I will examine whether it makes a difference how recently the practices were introduced. 
Make or Buy Firms have a choice between training their own employees or instead hiring employees who already possess the requisite skills. Driving this choice is the extent of available external supply, the extent to which the needed skills are highly firm-specific, the importance of socialization in firm procedures and culture, and the cost of internal training.

The survey asked about the first and second most important hiring criteria and I recoded the open-ended replies into several categories: prior skills, personality and behavioral traits, and ability to learn. In the models that follow I include a dummy variable which takes of the value of " 1 " if prior skill was both the first and the second most important hiring criteria for CORE jobs.

Employee Characteristics Previous literature on training (e.g. Lynch 1991) has demonstrated that women tend to receive less on-the-job training than do men and that training is positively correlated with level of education. I include variables measuring the percent of the CORE employees who are women and the average educational attainment of CORE employees. 25

Internal Labor Market Structure The risk inherent in substantial training investments is that employees will leave and take the training investment with them. Internal labor market structures which create incentives to remain are a solution to this problem (Lazear 1987; Ryan 1984; Doeringer and Piore 1972). Three variables capture several alternative policies along these lines. The establishments were asked how much preference was given to internal vs. external candidates in filling vacancies in the internal labor market and they were also asked how much weight was given to seniority in choosing among internal candidates for promocion. These are two measures of job ladders and are included in the models. ${ }^{26}$

In addition to job ladders another commonly cited strategy for retaining employees is to pay above market wages. This strategy, sometimes termed "efficiency wages," can pay for itself provided that the gains, in this case reduced turnover and retention of workers in whom the firm has invested, exceed the cost. The survey asked whether the establishment paid CORE workers a wage higher than that paid to comparable employees in local firms and a variable measuring the response is included. ${ }^{27}$

Skill and Technology The amount of training should obviously be related to the level of skill required in the job. This is measured by the variable SKLEV which takes on the value of " 1 " if the production process requires high levels of skill and " 0 " otherwise. ${ }^{28}$ In addition, standard human capital theory predicts that when skills are enterprise-specific training provided by the firm will be more extensive (because the fear of turnover will be lessened). The variable SPECIFIC measures the extent of skill specificity. ${ }^{29}$

Institutional Considerations There are several characteristics of the establishment which might be expected to influence the extent of training. One 
consideration is size. Most of the training literature has found that small firms provide less formal training than do large ones (Bishop, undated). This may be due to greater fears of turnover among small firms (who are less able to develop lengthy job ladders) or fewer resources or managerial slack to devote to training.

A second institutional consideration concerns the values of the enterprises' managers. The strategic choice literature in industrial relations (Kochan et al. 1986) suggests that managerial values may be important in selection of work organization and this may also be true with respect to the degree of investment in the work force. The values variable will be the same question employed earlier regarding attitudes toward the personal and family welfare of employees.

The presence or absence of a union may be important. Unions can be expected to serve as a pressure group, or voice mechanism, pushing for increased investment in employees and hence one would expect a positive association between unionism and training effort. On the other hand, unions sometimes may act as protectors of traditional job rights and this may diminish the extent of training.

The sociological literature on institutions suggests that certain "non-market" considerations may influence the extent of training programs (Meyer and Scott 1991). The survey asked whether or not the establishment was part of a larger organization. If it is then pressures for organizational conformity and legitimation within the context of bureaucratic structures may lead to more extensive training (DiMaggio and Powell 1983; Pfeffer and Cohen 1984; Baron et al. 1988). In addition, establishments that are part of larger organizations (e.g. a branch plant) may receive greater resources, information, and technical assistance. A dummy variable LARGER takes on the value of " 1 " if the establishment is part of larger organization.

In general, it is reasonable to expect that the greater importance an establishment gives to human resources as part of its competitive strategy the greater the effort devoted to training. The survey asked "when senior management makes important decisions regarding long-run competitiveness how important are human resource considerations?" If the reply was very or extremely important, the variable HRROLE was coded "1."

Finally, controls are included for the occupational group of the CORE job. As already noted, most prior research suggests that, all else constant, blue-collar workers receive less training than do higher level whire-collar employees.

\section{Results}

Variable means and definitions are provided in Table 2.6 and Table 2.7 contains the estimated model. Because the dependent variable-percentage of the CORE employees who receive formal off-the-job training-is truncated both at zero and one hundred the appropriate estimation technique is the Tobit model.

The central findings are:

1 Use of high performance work systems are positively associated with increased training effort. 
2 There is, indeed, a trade-off between make or buy. Firms which place heavy emphasis on hiring employees with previously acquired skills are less likely to provide training. ${ }^{30}$

3 The fraction of the CORE labor force that is female is negatively associated with training effort. On the other hand, there is no relationship between education level and training.

4 The more highly skilled the CORE job, the more training is provided. However, contrary to expectations, jobs with specific skills are less likely to include employer provided training. This is the only coefficient in the model which is directly inconsistent with prior expectations.

5 Jobs ladders do not seem to be related to training. However, payment of efficiency wages is associated with higher levels of training.

6 Values are strongly related to training propensity. Two additional institutional variables are also important: The importance accorded to human resource considerations and whether or not the establishment is part of a larger organization. In addition, unionism is also significantly related to training effort by establishments.

7 Blue-collar employees are, all else equal, less likely to be the recipients of formal off-the-job training than are white-collar workers. The same is true for service employees.

In summary this equation performs very well. It is clear that the new "conventional wisdom" is correct: flexible forms of work organization are associated with heightened training. It is also apparent that the training effort of a given establishment is determined by a mix of standard economic as well as institutional considerations.

Returning to the theme of the relationship of work organization to training, one additional question can be addressed: Whether the impact of flexible work organization upon skill and training is permanent or rather associated with the recency of the innovation. Table 2.8 presents the coefficients of the work organization variables using alternative specifications which address these questions (the rest of the equations are the same as the earlier one).

The survey asked firms the date at which they introduced each of the work organizational innovations which are captured in the index. In the first panel the index includes only those innovations which had been in existence for longer than five years at the time of the survey while in the second panel only those innovations which are five years or younger are included. It is clear that the positive impact of flexible work organization upon training holds true only for the more recently introduced innovations. The most natural interpretation of this finding is that once the innovation has been in place for a length of time it becomes sufficiently routinized so that additional training (beyond that provided by establishments which have not introduced the work organization changes) is not necessary. This, however, is speculative and alternative interpretations are also possible. ${ }^{31}$ 


\section{A BRIEF COMPARISON WITH GERMANY}

There is no survey of German establishments which is comparable to the U.S. survey employed above. It is not possible, therefore, to engage in comparative econometric modeling of work systems and training. It is, however, possible to draw on a variety of sources to develop a rough sense about how patterns of work organization compare across the two nations.

The standard story is that several elements of the German industrial relations system combine to bias firms strongly in the direction of what we have here termed "high performance work systems." These elements include extensive but broad occupational training generated by the dual apprenticeship system, the presence and substantial power of works councils in most establishments, strong industrial unions, and inhibitions on layoffs. The training system provides the skill basis for high performance work and also makes the implementation of such systems cheaper for any given firm. Works councils provide an internal lobby for broadening work and for using employees to their maximum potential. The strong unions make it difficult to use wage cutting as a competitive strategy and this helps force employers on the "high road." Layoff restrictions commit the firm to making the most of its incumbent work force (Streeck 1988).

A series of industry studies, some within Germany and some comparing Germany to other nations, support the view that the logic outlined above is operative. Peter Berg concludes from his comparison of U.S. and German auto plants that "In general, German plants show greater willingness to move away from traditional Taylorism and expand the use of labor than U.S. plants." (Berg 1992: 12). Berg also finds that the plants that make greater use of flexible work systems also engage in more training. In a similar vein, Lowell Turner and Peter Auer find that auto plants in Germany are converging to the use of teams (termed "group work"), total quality management, and just-in-time inventory systems (Turner and Auer 1992). Turner and Auer caution that the actual implementation of these workplace innovations varies in important ways across sites and across nations. However the broad picture they paint is movement toward flexibility in Germany.

Kern and Schumann (1989) examine chemicals, electronics, and machine building as well as automobiles in Germany. On the basis of their survey they conclude that work is becoming more skilled and that a new occupational category, which they term "controllers," is emerging as the central player in these industries. These controllers are at the boundary of blue- and white-collar work and think of themselves as semi-professionals. Finally, the comparative studies conducted by $\mathrm{S}$. J. Prais and his colleagues at Britain's National Economic Institute confirm that Germany (compared to Britain) makes heavy use of skilled employees in settings which give them considerable autonomy.

Taken as a whole these case studies and limited surveys provide reasonably convincing evidence that what I have termed high performance work organizations are widespread in Germany and that their incidence is increasing. Having said this, we must also recognize that we have said nothing about the economic performance 
of these work systems. Indeed, the recent difficulties of the German economy and the widespread perception that the cost structure of German firms may be too high raises difficult issues about the interrelationship between the physical productivity gains that flexible work systems seem to provide and the costs associated with attaining and maintaining these systems. This important question should be the topic of further research.

\section{ACKNOWLEDGMENTS}

This research was supported by a grant from the Spencer Foundation. I am grateful to Peter Cappelli, Thomas Kochan, Frank Levy, Harry Katz, Michael Massagli, Richard Murnane, Jim Rebitzer, and the conference organizers for comments on an earlier draft of this paper. Portions of this paper have appeared in "How Common is Workplace Transformation and How Can We Explain Who Does It" in the January, 1994 issue of the Industrial and Labor Relations Review and in "Skill, Training, and Work Organization In American Establishments," Industrial Relations, forthcoming.

\section{NOTES}

1 The response rate to the widely cited Training Magazine survey was 15.8 percent.

2 After eliminating cases with missing variables and a few establishments that slipped into the survey inappropriately the final sample size used in this chapter is 694 .

3 In their comparison of this file with alternative sampling frames (the unemployment insurance files, the telephone White pages, direct enumeration, and Chamber of Commerce membership listings) Kalleger et al (1990) found that for a local area the Dun and Bradstreet file and the unemployment insurance files yield representative samples and are the most preferred. For creating a national sample the Dun and Bradstreet file is the only practical choice.

4 While in many cases a human resources person might be appropriate I wanted to avoid an automatic selection of people in this position. The reason for the concern was that years of open-ended interviews with firms suggested to me that too often HR staff, even at the establishment level, are not in touch with work organization. Therefore, the introductory letter said

In order to get the best possible answers we need the cooperation of the most senior person at your location in charge of production of goods and services. For example, in manufacturing this might be the plant manager. In a nonmanufacturing setting it might be the head of the office or the manager responsible for operations.

The interviewers worked with the establishment to identify the most knowledgeable respondent. In the end 46 percent of the respondents worked in the human resources function.

5 According to the Dun and Bradstreet file, establishments with 50 or more employees represent just 10 percent of all establishments. However, according to the May, 1988 Current Population Survey they represent 51 percent of all employees.

6 The survey was conducted by the University of Massachusetts Center for Survey Research. The response rate is well above that of other comparable surveys. It is possible 


\section{PAUL OSTERMAN}

to estimate response rate bias by using variables in the Dun's file. I estimate a logit model in which the dependent variable was the probability of response and the independent variables were size, a dummy if the establishment was manufacturing, a dummy variable if the establishment was a headquarters of a multibranch firm, and a dummy variable if the establishment was not part of a larger enterprise. The manufacturing dummy and the headquarters dummy were significant. Transforming the coefficient at the mean value of the variables indicated that the probability of response increased by 5 percentage points if the respondent was manufacturing. A similar calculation revealed that probability of response decreased by 8 percentage points if the establishment was a headquarters. However, even among nonmanufacturing headquarter firms the response rate in the survey was 59.1 percent. The weights used in this chapter are adjusted to reflect nonresponse.

7 As several people have pointed out, the survey did not directly observe the actual work practices. There may be a tendency of respondents to exaggerate, in the direction of socially acceptable responses, their actual practices. However, as already noted, considerable care was taken to work with the most knowledgeable available respondent. Furthermore, as the statistical results below demonstrate, the responses are not simply noise; they are correlated in sensible ways with explanatory variables. Nonetheless, as is true in all surveys of this kind, the point estimates of the practices should be treated with caution.

8 The results of Lawler et al. (1992) are broadly consistent with mine. They find that 56 percent of the Fortune 1000 firms in their sample have quality circles and that 47 percent have self-managed work teams. In both cases the modal degree of penetration is below 20 percent for those firms which do have the practice (Lawler et al 1992: 20-22).

9 Jan Klein (1991) suggests that this may be because self-managed work teams place strains on the inventory management system in manufacturing.

10 The Commission on the Skills of the American Workforce used the criteria of whether firms hired on the basis of a skill as opposed to behavior or ability to "get along." They assumed that firms which sought hard skills used them and hence were high performance organizations. The distinction between hard skills and behavioral skills is not conceptually clear, nor is the assumption that one can go from knowing about hring rules to understanding work organization. However, leaving aside these problems the current survey can also provide estimates along these lines. We asked establishments an openended question of what were their first and second most important hiring criteria for CORE jobs. We coded their responses into various categories. By the criteria of establishments which listed hard skills as their first most important hiring criteria 36.2 percent were high performance and if we use the more stringent standard of hard skills being both the first and second most important criteria then the figure is 13.2 percent.

11 The respondent was asked whether there were many firms selling products or services which competed with the establishment, a few firms, or no such firms. The variable is coded " 1 " if there are many competing firms and " 0 " if there are no competing firms or a few competing firms.

12 For example, in the automobile industry quality circles were included in contract language as early as 1973 but were only implemented on a wide scale after pressure from Japanese competitors became intense (Katz 1985).

13 The eigenvalue for the first component was 1.896 and the proportion of variance accounted for by this component was 63.2 percent.

14 Respondents were asked to characterize the skill level of the CORE jobs on a 1-5 scale and SKLEV is coded " 1 " if the reply was very skilled or extremely skilled.

15 In the computer industry Data General and Digital Equipment Corporation come to mind as pairs of firms which over the years have had very different approaches. In the steel industry USX and National or Inland are examples. 
16 The distribution of responses on the five-point scale was 1.7 percent "not appropriate," 9.4 percent "a little appropriate," 33.0 percent "moderately appropriate," 42.9 percent "very appropriate," and 12.8 percent "extremely appropriate."

17 The respondent was asked to indicate on a five-point scale the extent of pressure the establishment felt from investors or any larger organization of which it was part to attain short-term profits at the expense of long-term investments. This five-point scale was recoded into a dummy variable which takes on the value of " 1 " if the respondent felt "very much pressure" or "extreme pressure."

18 Cases were dropped in which there were missing values on the usage of any of the practices. In addition, three establishments in mining were dropped because of collinearity problems.

19 The index is $0.55 *$ TQM Penetration $+0.43 *$ Team Penetration $+0.38 *$ Rotation penetration + 0.59*Quality Circle Penetration. The first principal component accounted for 44 percent of the variance and had an eigenvalue of 1.752 .

20 In unreported regressions (using Tobit models) I also estimated models in which the dependent variables were the percentage penetration of each practice. The results of these equations are available upon request. The results are generally comparable, but slightly weaker, than those reported here. In particular, the strategy variable and the variable measuring whether the establishment is part of a larger organization were significant in the questions for teams and job rotation but not in the quality circles or TQM equations.

21 In order to interpret logit coefficients as the marginal change in a probability given a one-unit change in the independent variable they need to be transformed. The transformation is evaluated at the mean probability in the sample.

22 Causality may run in the other direction, however. That is only firms that are productive due to their adoption of flexible work organization are able to compete internationally. In order to resolve the direction of causality, data on timing both of work reforms and entry into international markets are necessary.

23 Lawler et al. (1992) present the results of significance tests of simple (i.e. unconditional) correlation coefficients between presence of TQM and some independent variables. They find that size, manufacturing, and presence of foreign competition of positively correlated with use of TQM while unionization is negatively correlated (Lawler et al 1992: 97-98).

24 In addition to the practices analyzed earlier, the use of Statistical Process Control is included here.

25 The respondent was asked to characterize the education level of CORE employees as being "mostly dropouts," "about equal high school dropouts and graduates (with no further education)," "mostly high school graduates," "about equal, high school graduates and at least some college," "mostly at least some college." In this model the dummy variable takes on the value of " 1 " if the response was in the first three categories (mostly high school graduates or less) and "0" otherside.

26 Two variables were created to measure ladders: One if the respondent said that when a vacancy occurred it was very or extremely important to fill it with insiders (versus not important, slightly important, or moderately important) and one that used the same scale to measure whether seniority was used as a criteria for choosing which insiders to promote.

27 The question asked was whether for the establishment's CORE employees there was a policy in place to pay wages which were higher, the same as, or lower than employees in comparable occupations in the same industry in the same geographic area. The variable is coded as " 1 " if the policy was to pay a higher wage.

28 Respondents were asked to characterize the skill level of the CORE jobs on a 1-5 scale and SKLEV is coded " 1 " if the reply was very skilled or extremely skilled. 


\section{PAUL OSTERMAN}

29 Respondents were asked whether the skills in the CORE job were easy to transfer, moderately difficult to transfer, or very difficult to transfer to firms in other industries. A dummy variable was coded " 1 " if the skills were very difficult to transfer.

30 Richard Murnane points out to me that this finding may be inconsistent with the common observation that more educated employees (who receive higher pay offers) also receive more training by firms. However, the finding in this chapter is best interpreted as referring to particular skills, not general education.

31 For example, the actual substance of the work organization innovation may differ across period of time.

\section{REFERENCES}

Adler, P. (1993) “The New 'Learning Bureaucracy': New United Motor Manufacturing, Inc.," Research In Organizational Behavior 15: 111-194.

Auer, P. (1989) "Technological Innovation and Accompanying Measures," Report to the Commission on European Communities, Tender No. 88/010/V, Berlin.

- (ed.) (1991) "Workforce Adjustment Patterns in Four Countries: Experiences in the Steel and Automobile Industry in France, Germany, Sweden, and the United Kingdom," Berlin: Wissenschaftszentrum Berlin Für Sozialforschung, FSI91-4.

Bailey, T. and Merritt, D. (1992) "Discretionary Effort and the Organization of Work: Employee Participation and Work Reform Since Hawthorne," New York: Columbia University, Teachers College.

Baron, J., Jennings, P. D. and Dobbin, F. (1988) "Mission Control? The Development of Personnel Systems in U.S. Industry," American Sociological Review 53, August: 497-514.

Batt, R. and Osterman, P. (1993) "A National Framework for Employment and Training Policy; Lessons from Local Initiatives," Washington, D.C.: Economic Policy Institute.

Berg, P. (forthcoming) "Strategic Adjustments in Training: A Comparative Analysis of the United States and German Automobile Industries," in L. Lynch (ed.), International Comparisons of Private Sector Training, Chicago: University of Chicago Press.

Bishop, J. (undated) "On the Job Training In Small Business," Washington, D.C., Office of Advocacy of the Small Business Administration, report on Grant \#SB-1A-00063-01-0.

Brown, C. (1990) "Empirical Evidence on Private Sector Training," in Research In Labor Economics, Greenwich: JAI Press.

Brown, Clair, Reich, M. and Stern, D. (1991) "Skills and Security in Evolving Employment Systems; Observations from Case Studies," mimeo, Institute of Industrial Relations, U.C. Berkeley.

Cappelli, P. and Sherer, P. D. (1989) "Spanning the Union/Nonunion Boundary," Industrial Relations 28, 2, Spring: 188-205.

Carnevale, A., Gainer, L. J. and Villet, J. (1990) Training in America, San Francisco: Jossey Bass.

Cuomo Commission on Trade and Competitiveness (1988) The Cuomo Commission Report, New York: Simon \& Schuster.

Commission on The Skills of The American Workforce (1990) America's Choice: High Skills or Low Wages, Washington, D.C.: National Center on Education and the Economy.

Delaney, J., Lewin, D. and Ichniowski, C. (1989) "Human Resource Policies and Practices in American Firms," Washington, D.C.: U.S. Department of Labor (BLMR Report No. 137).

Dertouzos, M., Lester, R. and Solow, R. (1989) Made In America, Cambridge, MA: MIT Press.

DiMaggio, P. and Powell, W. (1983) "The Iron Cage Revisited: Institutional Isomorphism and Collective Rationality in Organizational Fields," American Sociological Review 48: $147-160$. 
Doeringer, P. and Piore, M. (1972) Internal Labor Markets And Manpower Analysis, Lexington, MA: D.C. Heath.

Dore, R. (1973) British Factory, Japanese Factory, Berkeley: University of California Press.

Florida, R. and Kenney, M. (1991) "The Transfer of Japanese Industrial Organization to the U.S.," American Sociological Review 56, June: 381-398.

Ichniowski, C. (1990) "Human Resource Management Systems and the Performance of U.S. Manufacturing Business," NBER Working Paper No. 3449.

Jacobs, M. (1991) Short-Term America, Boston: Harvard Business School Press.

Kalleberg, A., Marsden, P., Aldrich, H. and Cassell, J. (1990) "Comparing Organizational Sampling Frames," Administrative Sciences Quarterly 35: 658-688.

Katz, H. (1985) Shifting Gears: Changing Labor Relations in the U.S. Auto Industry, Cambridge, MA: MIT Press.

Katz, L. and Murphy, K. (1987) "Changes in Relative Wages, 1963-1987: Supply and Demand Factors," Quarterly Journal of Economics 107, February: 35-78.

Keefe, J. (1991) "Numerically Controlled Machine Tools and Worker Skills," Industrial and Labor Relations Review 44: 503-519.

Kelley, M.-E. (1989) "Unionization and Job Design Under Programmable Automation," Industrial Relations 28, Spring: 174-187.

Kern, H. and Schumann, M. (1989) "New Concepts of Production in West German Plants," in P. Katzenstein (ed.), Industry and Politics in West Germany, Ithaca: Cornell University Press.

Klein, J. (1991) "A Reexamination of Autonomy in Light of New Manufacturing Practices," Human Relations 44, 1: 21-38.

Kochan, T., Katz, H. and McKersie, R. (1986) The Transformation of American Industrial Relations, New York: Basic Books.

Kochan, T. and Osterman, P. (1990) "Employment Security and Employment Policy, An Assessment of the Issues," in K. Abraham and R. McKersie, (eds) New Developments in the Labor Market, Cambridge, MA: MIT Press.

- (1991) "Human Resource Development; Does the United States Do Too Little?" paper prepared for the American Council on Competitiveness.

Lawler, E., Mohrman, S. and Ledford, G. (1992) Employee Involvement and Total Quality Management; Practices and Results in Fortune 1000 Companies, San Francisco: JosseyBass.

Lazear, E. (1987) “Why Is There Mandatory Retirement?" Journal of Political Economy 87, December: 1261-1284.

Levine, D. and D'Andrea Tyson, L. (1990) "Participation, Productivity, and the Firm's Environment" in A. Blinder (ed.), Paying for Productivity, Washington, D.C.: The Brookings Institution.

Lincoln, J. and Kalleberg, A. (1990) Culture, Control, and Commitment: A Study of Work Organization and Work Artifacts in the United States and Japan, Cambridge: Cambridge University Press.

Lynch, L. (1990) "The Private Sector and Skill Formation in the United States: A Survey," Working Paper \#3125-90-BPS, Cambridge, MA: MIT.

- (1991) "The Role of Off-the-Job Training For the Mobility of Women Workers," American Economic Review 81, 2: 151-156.

Lusterman, S. (1985) Trends in Corporate Education and Training, New York: The Conference Board.

MacDuffie, J. P. (1991) "Beyond Mass Production, Flexible Production Systems and Manufacturing Performance in the World Auto Industry," Unpublished Ph.D. Dissertation, MIT Sloan School of Management.

Madalla, G. S. (1983) Limited Dependent and Qualitative Variables in Econometrics, New York: Cambridge University Press. 


\section{PAUL OSTERMAN}

Milkman, R. (forthcoming) "California's Japanese Factories; Labor Relations and Economic Globalization," Los Angeles: UCLA Institute of Industrial Relations.

National Research Council (1986) Human Resource Practices for Implementing Advanced Manufacturing Technology, Washington, D.C.: National Academy Press.

Nunnally, J. (1978) Psychometric Theory, New York: McGraw Hill.

Osterman, P. (1987) "Choice Among Alternative Internal Labor Market Systems," Industrial Relations, February: 46-67.

- (1988) Employment Futures: Reorganization, Dislocation, and Public Policy, New York: Oxford University Press.

- (1993) "Internal Labor Markets In a Changing Environment; Models and Evidence," in D. Lewin, O. Mitchell, and P. Sherer (eds), Research Frontiers In Industrial Relations Madison, WI: Industrial Relations Research Association.

_- (1994) "How Common Is Workplace Transformation and How Can We Explain Who Does It," Industrial and Labor Relations Review, January.

___ (forthcoming) "Skill, Training, and Work Organization In American Establishments," Industrial Relations.

Pfeffer, J. and Cohen, Y. (1984) "Determinants of Internal Labor Markets in Organizations," Administrative Science Quarterly 29: 550-572.

Porter, M. (1992) Capital Choices; Changing The Way America Invests In Industry, Washington, D.C.: Council on Competitiveness.

Ryan, P. (1984) "The Theory of Training and Internal Labor Markets," in P. Osterman (ed.), Internal Labor Markets, Cambridge, MA: MIT Press.

Schumann, M. (1990) "Technological and Organizational Development in West Germany: The Impact of Work," paper presented at the Symposium on Work and Welfare, University of Karlstad, Sweden, June.

Scott, R. and Meyer, J. (1991) "The Rise of Training Programs in Firms and Agencies; An Institutional Approach," in Research in Organizational Behavior, Greenwich, CT: JAI Press.

Stinchcombe, A. (1965) "Social Structure and Organization," in J. March (ed.), Handbook of Industrial Organization, Chicago: Rand McNally.

Streeck, W. (1988) "Successful Adjustment to Turbulent Markets: The Automobile Industry," Berlin: Wissenschaftszentrum Berlin für Sozialforschung, FSI88-1.

Turner, L. and Auer, P. (1992) "The Political Economy of New Work Organization; Different Roads, Different Outcomes," Berlin: Wissenschaftszentrum Berlin für Sozialforschung, FSI92-4.

Walton, R. (1985) "From Control to Commitment in the Workplace," Harvard Business Review, March/April: 77-84.

Womak, J., Jones, D. and Roos, D. (1990) The Machine that Changed the World, New York: Rawson-Macmillan.

\section{APPENDIX A}

The following are the definitions that the interviewers used when the respondent requested clarification.

Self-directed Work Teams Employees supervise their own work, workers make their own decisions about pace and flow and occasionally the best way to get work done.

Job Rotation Self-explanatory example: In some banking firms you spend six months in the real estate division, six months in pension plans, etc. Simply rotating jobs. 
WORK ORGANIZATION AND TRAINING IN AMERICAN ENTERPRISES

Problem-solving Groups/Quality Circles Quality programs where employees are involved in problem solving.

Total Quality Management Quality control approach that emphasizes the importance of communications, feedback, and teamwork.

\section{APPENDIX B}

Table 2.1 (a) Percent at any Percent Level of Penetration

\begin{tabular}{lcc}
\hline & $\begin{array}{c}\text { All } \\
\%\end{array}$ & $\begin{array}{c}\text { Manufacturing } \\
\%\end{array}$ \\
\hline Teams & 54.5 & 50.1 \\
Rotation & 43.4 & 55.6 \\
TQM & 33.5 & 44.9 \\
QC & 40.8 & 45.6 \\
Nothing & 21.8 & 16.0 \\
\hline
\end{tabular}

Table 2.1(b) Percent at 50 Percent Level of Penetration

\begin{tabular}{lcc}
\hline & $\begin{array}{c}\text { All } \\
\%\end{array}$ & $\begin{array}{c}\text { Manufacturing } \\
\%\end{array}$ \\
\hline Teams & 40.5 & 32.3 \\
Rotation & 26.6 & 37.4 \\
TQM & 24.5 & 32.1 \\
QC & 27.4 & 29.7 \\
Nothing & 36.0 & 33.2 \\
\hline
\end{tabular}

Table 2.2 Clustering of Work Practices (50 percent or more penetration)

\begin{tabular}{lcc}
\hline & $\begin{array}{c}\text { Entire Sample } \\
\%\end{array}$ & $\begin{array}{c}\text { Manufacturing/Blue Collar } \\
\%\end{array}$ \\
\hline Nothing & 36.0 & 33.2 \\
All & 4.8 & 5.0 \\
Teams only & 14.4 & 5.5 \\
Rotation only & 7.0 & 11.7 \\
QC only & 3.1 & 2.4 \\
TQM only & 2.6 & 4.5 \\
Team/Rotation & 4.8 & 4.6 \\
Team/QC & 4.3 & 3.3 \\
Team/TQM & 4.6 & 4.2 \\
Rotation/QC & 3.0 & 3.3 \\
Rotation/TQM & 1.5 & 4.5 \\
TQM/QC & 4.4 & 4.9 \\
Team/TQM/QC & 3.6 & 4.2 \\
Team/Rotation/TQM & 1.2 & 1.6 \\
Team/Rotation/QC & 2.3 & 3.4 \\
Rotation/TQM/QC & 1.4 & 2.9 \\
\hline
\end{tabular}


PAUL OSTERMAN

Table 2.3 Definition of Variables

\begin{tabular}{|c|c|c|}
\hline Variable & Definition & Mean \\
\hline Union & $\begin{array}{l}1=A \text { union is present } \\
0=\text { No union }\end{array}$ & 0.237 \\
\hline Age & Years since establishment founded & 24.675 \\
\hline Competitive & $\begin{array}{l}1=\text { establishment's product market is competitive } \\
0=\text { not }\end{array}$ & 0.619 \\
\hline International & $\begin{array}{l}1=\text { establishment sells in international markets } \\
0=\text { not }\end{array}$ & 0.311 \\
\hline Horizon & $\begin{array}{l}1=\text { feels pressure from investors or large organization for } \\
\text { short-term profits } \\
0=\text { not }\end{array}$ & 0.219 \\
\hline Skill & $\begin{array}{l}1=\text { CORE job very or extremely skilled } \\
0=\text { not }\end{array}$ & 0.369 \\
\hline Larger & $\begin{array}{l}1=\text { establishment part of a larger organization } \\
0=\text { not }\end{array}$ & 0.660 \\
\hline Strategy & $\begin{array}{l}\text { Principal component of points assigned to variety, service, } \\
\text { and quality relative to cost }\end{array}$ & -0.004 \\
\hline Values & $\begin{array}{l}1=\text { it is very or extremely appropriate for establishment to } \\
\text { accept responsibility for personal and family well } \\
\text { being of employees } \\
0=\text { otherwise }\end{array}$ & 0.552 \\
\hline Size 1 & 1 = establishment has 50-99 employees & 0.509 \\
\hline Size 3 & $1=$ establishment has 500-999 employees & 0.048 \\
\hline Size 4 & $1=$ establishment has 1000-2499 employees & 0.026 \\
\hline Size 5 & $1=$ establishment has $2500+$ employees & 0.006 \\
\hline
\end{tabular}


WORK ORGANIZATION AND TRAINING IN AMERICAN ENTERPRISES

Table 2.4 Determinants of Flexible Work Practices (T Statistics)

\begin{tabular}{|c|c|c|c|}
\hline & $\begin{array}{l}\text { Logit; Any } \\
\text { Practice } \\
\geqslant 50 \%\end{array}$ & $\begin{array}{c}\text { Principal } \\
\text { Components, } \\
\text { Four Practices }\end{array}$ & $\begin{array}{l}\text { Ordered Probit; } \\
\text { No. of Practices } \\
\geqslant 50 \%\end{array}$ \\
\hline UNION & $\begin{array}{c}0.067 \\
(1.211)\end{array}$ & $\begin{array}{c}-0.176 \\
(1.461)\end{array}$ & $\begin{array}{c}-0.110 \\
(0.973)\end{array}$ \\
\hline $\mathrm{AGE}$ & $\begin{array}{c}-0.001 \\
(1.984)\end{array}$ & $\begin{array}{c}-0.001 \\
(0.551)\end{array}$ & $\begin{array}{c}-0.001 \\
(0.738)\end{array}$ \\
\hline COMPETIV & $\begin{array}{c}0.065 \\
(1.431)\end{array}$ & $\begin{array}{c}-0.197 \\
(1.989)\end{array}$ & $\begin{array}{c}-0.079 \\
(0.836)\end{array}$ \\
\hline INTERNAT & $\begin{array}{c}0.172 \\
(3.194)\end{array}$ & $\begin{array}{c}0.267 \\
(2.338)\end{array}$ & $\begin{array}{c}0.330 \\
(3.05)\end{array}$ \\
\hline HORIZON & $\begin{array}{c}-0.017 \\
(0.347)\end{array}$ & $\begin{array}{c}0.066 \\
(0.587)\end{array}$ & $\begin{array}{c}0.026 \\
(0.248)\end{array}$ \\
\hline LARGER & $\begin{array}{c}0.090 \\
(1.827)\end{array}$ & $\begin{array}{c}0.575 \\
(5.371)\end{array}$ & $\begin{array}{c}0.441 \\
(4.21)\end{array}$ \\
\hline VALUES & $\begin{array}{c}0.163 \\
(3.854)\end{array}$ & $\begin{array}{c}0.578 \\
(6.131)\end{array}$ & $\begin{array}{c}0.509 \\
(5.56)\end{array}$ \\
\hline SKILL & $\begin{array}{c}0.099 \\
(1.956)\end{array}$ & $\begin{array}{c}0.410 \\
(3.781)\end{array}$ & $\begin{array}{c}0.300 \\
(2.92)\end{array}$ \\
\hline STRATEGY & $\begin{array}{c}0.058 \\
(2.906)\end{array}$ & $\begin{array}{c}0.079 \\
(2.378)\end{array}$ & $\begin{array}{c}0.108 \\
(3.43)\end{array}$ \\
\hline SIZE 1 & $\begin{array}{c}0.083 \\
(1.767)\end{array}$ & $\begin{array}{c}0.264 \\
(2.549)\end{array}$ & $\begin{array}{c}0.325 \\
(3.25)\end{array}$ \\
\hline SIZE 3 & $\begin{array}{c}-0.317 \\
(3.254)\end{array}$ & $\begin{array}{c}-0.567 \\
(2.646)\end{array}$ & $\begin{array}{c}-0.647 \\
(3.06)\end{array}$ \\
\hline SIZE 4 & $\begin{array}{c}0.177 \\
(1.269)\end{array}$ & $\begin{array}{c}0.183 \\
(0.646)\end{array}$ & $\begin{array}{c}0.263 \\
(0.983)\end{array}$ \\
\hline SIZE 5 & $\begin{array}{c}-0.192 \\
(0.783)\end{array}$ & $\begin{array}{c}-0.211 \\
(0.382)\end{array}$ & $\begin{array}{c}-0.257 \\
(0.495)\end{array}$ \\
\hline CONSTANT & $\begin{array}{c}-0.478 \\
(3.533)\end{array}$ & $\begin{array}{c}-1.715 \\
(6.126)\end{array}$ & $\begin{array}{c}-0.257 \\
(0.495)\end{array}$ \\
\hline Log Likelihood & -388.467 & $\mathrm{R}^{2}=0.242$ & -886.67 \\
\hline $\mathrm{N}$ & 694 & 694 & 694 \\
\hline
\end{tabular}

Note: The equations also include controls for CORE occupation and industry. 


\section{PAUL OSTERMAN}

Table 2.5 Skill Level and Skill Trends

\begin{tabular}{lccc}
\hline & $\begin{array}{c}\text { All } \\
\%\end{array}$ & $\begin{array}{c}\text { Blue Collar } \\
\%\end{array}$ & $\begin{array}{c}\text { Professional/Technical } \\
\%\end{array}$ \\
\hline Skill Level & & & \\
$\quad$ Not skilled & 1.8 & 0.2 & 0.0 \\
$\quad$ Slight skill & 19.5 & 23.7 & 0.0 \\
$\quad$ Moderate skill & 43.2 & 57.2 & 14.5 \\
$\quad$ Very skilled & 28.1 & 18.7 & 63.9 \\
$\quad$ Extremely skilled & 7.2 & 0.05 & 21.5 \\
Change in skill & & & \\
$\quad$ No change & 38.1 & 37.4 & 0.0 \\
$\quad$ Less complex & 3.5 & 11.4 & 51.1 \\
$\quad$ More complex & 39.9 & 36.0 & 19.7 \\
$\quad$ Same level, Different skill & 17.7 & 15.1 & \\
\hline
\end{tabular}

Table 2.6 Variable Definitions and Means

\begin{tabular}{|c|c|c|}
\hline Variable & Definition & Mean \\
\hline Trnper & $\begin{array}{l}\text { Percent of CORE employees who receive formal off-the-job } \\
\text { training }\end{array}$ & 0.320 \\
\hline Edu & $\begin{array}{l}1 \text { if most CORE employees have a high school degree or less } \\
\text { education; } 0 \text { otherwise }\end{array}$ & 0.61 \\
\hline Per Fem & Percentage of CORE employees who are women & 0.435 \\
\hline Wage & $\begin{array}{l}1 \text { if establishment pays CORE employees more than } \\
\text { comparable workers in the same occupation in the same } \\
\text { industry in the local area; } 0 \text { otherwise }\end{array}$ & 0.365 \\
\hline Specific & $\begin{array}{l}1 \text { if it is very or extremely difficult to use the skills of the } \\
\text { CORE job elsewhere; } 0 \text { otherwise }\end{array}$ & 0.139 \\
\hline Ladder 1 & $\begin{array}{l}1 \text { if it is very or extremely important to give preference to } \\
\text { insiders in filling vacancies; } 0 \text { otherwise }\end{array}$ & 0.708 \\
\hline Ladder2 & $\begin{array}{l}1 \text { if it is very or extremely important to use seniority to } \\
\text { determine which incumbents are promoted to vacancies; } \\
0 \text { orherwise }\end{array}$ & 0.303 \\
\hline Hpwo & $\begin{array}{l}\text { Number of Work Organization Innovations implemented at } \\
\text { the } 50 \text { percent or more level of penetration }\end{array}$ & 1.306 \\
\hline Hire Skill & $\begin{array}{l}1 \text { if skills are the first and second most important hiring criteria } \\
\text { for the CORE job; } 0 \text { otherwise }\end{array}$ & 0.133 \\
\hline Union & $\begin{array}{l}1=A \text { union is present } \\
0=\text { No union }\end{array}$ & 0.237 \\
\hline SkLev & $\begin{array}{l}1=\text { CORE job very or extremely skilled } \\
0=\text { not }\end{array}$ & 0.369 \\
\hline
\end{tabular}


Table 2.6 (Continued)

\begin{tabular}{|c|c|c|}
\hline Variable & Definition & Mean \\
\hline Larger & $\begin{array}{l}1=\text { establishment part of a larger organization } \\
0=\text { not }\end{array}$ & 0.660 \\
\hline Values & $\begin{array}{l}1=\text { it is very or extremely appropriate for establishment to } \\
\text { accept responsibility for personal and family well being of } \\
\text { employees } \\
0=\text { otherwise }\end{array}$ & 0.552 \\
\hline Size 1 & $1=$ establishment has 50-99 employees & 0.509 \\
\hline Size 3 & $1=$ establishment has 500-999 employees & 0.048 \\
\hline Size 4 & $1=$ establishment has $1000-2499$ employees & 0.026 \\
\hline Size 5 & $1=2500+$ employees & 0.006 \\
\hline HRrole & $\begin{array}{l}1 \text { if Human Resources Department involved in major strategic } \\
\text { decisions; } 0 \text { otherwise }\end{array}$ & 0.541 \\
\hline Blue Collar & 1 if CORE job blue collar & 0.423 \\
\hline Sales & 1 if CORE job sales & 0.190 \\
\hline Clerical & 1 if CORE job clerical & 0.060 \\
\hline Service & 1 if CORE job service & 0.183 \\
\hline Prof & 1 if CORE job professional/technical & 0.143 \\
\hline Recent Index & $\begin{array}{l}\text { Number of innovative work practices which have been } \\
\text { introduced in the past five years }\end{array}$ & 0.885 \\
\hline Old Index & $\begin{array}{l}\text { Number of innovative work practices which are more than five } \\
\text { years old }\end{array}$ & 0.420 \\
\hline $\begin{array}{l}\text { Percent in } \\
\text { Teams }\end{array}$ & $\begin{array}{l}\text { Average percent of CORE employees in teams (including } \\
\text { zeros) }\end{array}$ & 0.390 \\
\hline $\begin{array}{l}\text { Percent in } \\
\text { Rotation }\end{array}$ & $\begin{array}{l}\text { Average percent of CORE employees in job rotation } \\
\text { (including zeros) }\end{array}$ & 0.264 \\
\hline $\begin{array}{l}\text { Percent in } \\
\text { TQM }\end{array}$ & $\begin{array}{l}\text { Average percent of CORE employees in TQM (including } \\
\text { zeros) }\end{array}$ & 0.252 \\
\hline Percent in QC & $\begin{array}{l}\text { Average percent of CORE employees in quality circles } \\
\text { (including zeros) }\end{array}$ & 0.277 \\
\hline Percent in SPC & $\begin{array}{l}\text { Average percent of CORE employees in statistical process } \\
\text { control (including zeros) }\end{array}$ & 0.114 \\
\hline
\end{tabular}


Table 2.7 Tobit Estimate of Off-the-Job Training (T Statistics)

\begin{tabular}{|c|c|}
\hline Edu & $\begin{array}{c}0.009 \\
(0.146)\end{array}$ \\
\hline Per Fem & $\begin{array}{l}-0.195^{* *} \\
(-2.095)\end{array}$ \\
\hline Union & $\begin{array}{c}0.125^{*} \\
(1.774)\end{array}$ \\
\hline Values & $\begin{array}{c}0.238^{* *} \\
(4.404)\end{array}$ \\
\hline Larger & $\begin{array}{c}0.173^{* *} \\
(2.915)\end{array}$ \\
\hline Wage & $\begin{array}{l}0.125^{* *} \\
(2.312)\end{array}$ \\
\hline Size 1 & $\begin{array}{c}-0.369 \\
(-3.127)\end{array}$ \\
\hline Size 2 & $\begin{array}{c}-0.046 \\
(-0.402)\end{array}$ \\
\hline Size 4 & $\begin{array}{c}-0.026 \\
(-0.145)\end{array}$ \\
\hline Size 5 & $\begin{array}{c}-0.381 \\
(-1.200)\end{array}$ \\
\hline Specific & $\begin{array}{l}-0.184^{* *} \\
(-2.311)\end{array}$ \\
\hline Hire Skill & $\begin{array}{c}-0.221 \\
(-2.808)\end{array}$ \\
\hline Blue Collar & $\begin{array}{r}-2.97^{* *} \\
(-3.113)\end{array}$ \\
\hline Service & $\begin{array}{l}-0.286^{* *} \\
(-2.976)\end{array}$ \\
\hline Clerical & $\begin{array}{c}-0.093 \\
(-0.722)\end{array}$ \\
\hline Sales & $\begin{array}{c}-0.089 \\
(0.909)\end{array}$ \\
\hline Ladder 1 & $\begin{array}{c}0.011 \\
(0.197)\end{array}$ \\
\hline Ladder 2 & $\begin{array}{c}0.094 \\
(1.584)\end{array}$ \\
\hline Sklev & $\begin{array}{c}0.217^{* *} \\
(3.513)\end{array}$ \\
\hline HRrole & $\begin{array}{c}0.204^{* *} \\
(3.823)\end{array}$ \\
\hline HPWO & $\begin{array}{c}0.051^{* *} \\
(2.549)\end{array}$ \\
\hline Constant & $\begin{array}{c}0.135 \\
(0.816)\end{array}$ \\
\hline Log Likelihood & -629.227 \\
\hline $\mathrm{N}$ & 733 \\
\hline
\end{tabular}


Table 2.8 Coefficients for Alternative Work Practice Variables (T Statistics)

1. Recent Index

2. Old Index

3. Separate Practices

Percent in teams

Percent in rotation

Percent in TQM

Percent in QC

Percent in SPC
$-0.237$

$(-3.380)$

0.065

(2.991)

$-0.013$

$(-0.382)$

0.147

(2.048)

0.178

(2.411)

0.200

(2.158)

Note: Each panel refers to a Tobit equation which includes the additional variables shown in the preceding table. The "New Index" includes only the workplace innovations which had been put in place within five years of the survey and the "Old Index" includes only the innovations which had been put in place earlier than five years before the survey. The variables "percent in teams" and so on are the percentage of CORE workers involved in each of the practices. 